\title{
Media Informasi untuk Bank Baterai Berbasis Augmented Reality
}

\section{(Information Media of Battery Banks Based on Augmented Reality)}

\author{
Raymond Y. Purba ${ }^{1}$, Suci Aulia ${ }^{2}$, Agus Gunarso ${ }^{3}$
}

\begin{abstract}
Based on data from the pre-questionnaire related information media needs at PT. Telkom WITEL Bandung, $75 \%$ of employees have not known yet about battery bank information in detail and the rest of population only know from manual book and internet. The difficulty to get information from a device causes few actions and decisions that are not in accordance with standard procedures. On the other hand, manual book only give information concretely, making it difficult for employees to understand the information quickly and precisely which causes low reading interest. Implementation of Augmented Reality (AR) as a battery bank information media could be the best option of technology application that could deliver information digitally. In AR, users will get the experience that information appears directly like physical object so it would be more realistic, interactive, and easy to understand. In this study, a design of AR applications uses Luther Sutopo methodology based on Multimedia Development Life Cycle (MDLC) with AR Marker Based Tracking Type. The results of functional test show that the application is running properly and ready to be used as a battery bank information media system at PT. Telkom WITEL Bandung. This application can also be downloaded at Google Play Store.
\end{abstract}

Intisari-Berdasarkan data dari prekuesioner tentang kebutuhan media informasi di PT. Telkom WITEL Bandung, sebanyak $75 \%$ karyawan belum mengetahui tentang informasi bank baterai secara mendetail dan lainnya hanya mengetahui dari manual book dan internet. Sulitnya mendapatkan informasi dari suatu perangkat menyebabkan terjadinya berbagai tindakan dan keputusan yang tidak sesuai dengan standar prosedur yang telah ditetapkan. Di sisi lain, manual book menyajikan informasi secara konkret, sehingga menyulitkan para pegawai untuk memahami informasi secara cepat dan tepat yang menyebabkan menurunnya minat baca. Penerapan Augmented Reality (AR) sebagai media informasi bank baterai menjadi salah satu pemanfaatan teknologi yang tepat untuk menyampaikan informasi secara digital. Dengan AR, pengguna akan merasakan informasi muncul secara langsung seperti objek fisik ke dalam dunia nyata, sehingga menjadi lebih realistis, interaktif, dan mudah dipahami secara cepat dan tepat sesuai dengan standar prosedur yang telah ditetapkan. Pada makalah ini, perancangan aplikasi AR menggunakan metodologi Luther-Sutopo berbasis Multimedia Development Life Cycle (MDLC) dengan jenis AR Marker Based Tracking. Hasil pengujian fungsionalitas menunjukkan bahwa aplikasi sudah berjalan dengan baik dan siap untuk digunakan sebagai sistem

1,2 Universitas Telkom, Jl.Telekomunikasi No.1, Dayeuh Kolot Bandung 40257 INDONESIA (tlp: 022 7565930; e-mail: raymond@student.telkomuniversity.ac.id, suciaulia@telkomuniversity.ac.id)

${ }^{3}$ PT.Telkom Witel Bandung, Jl. Lembong No.11, Sumur Bandung Bandung 40111 INDONESIA (e-mail: 650565@telkom.co.id) media informasi bank baterai di PT. Telkom WITEL Bandung yang dapat diunduh di Google Play Store.

Kata Kunci-AR, Marker Based Tracking, Luther-Sutopo, MDLC.

\section{Pendahuluan}

Manual book yang terkesan konkret menjadikan sebagian besar kebiasaan karyawan malas untuk memperhatikan standar prosedur dan ketetapan dari suatu perangkat telekomunikasi. Pusat Data dan Informasi Kementerian Kesehatan RI mengemukakan bahwa besarnya potensi penyakit dan kecelakaan kerja bergantung pada jenis produksi, jenis bahan dan teknologi yang digunakan, lingkungan kerja, kualitas manajemen, dan tenaga pelaksana [1]. Sementara itu, sulitnya mendapatkan informasi dari suatu perangkat menyebabkan terjadinya berbagai tindakan dan keputusan yang tidak sesuai dengan standar prosedur yang telah ditetapkan. Berdasarkan data dari prekuesioner tentang kebutuhan media informasi di PT. Telkom WITEL Bandung yang dilakukan terhadap dua belas orang karyawan khusus di bagian baterai, sebanyak $75 \%$ karyawan belum mengetahui tentang informasi bank baterai (battery bank) secara mendetail. Selain itu, 75\% karyawan juga menyatakan bahwa media yang menyediakan detail informasi tentang bank baterai hanyalah manual book dan internet. Kemudian, $75 \%$ karyawan juga merasa kesulitan dalam mendapatkan detail informasi tentang bank baterai. Angka ini mengindikasikan bahwa perlu disediakan media informasi untuk bank baterai yang ada di PT. Telkom WITEL Bandung. Oleh karena itu, perlu dirancang suatu sistem informasi bank baterai yang bersifat interaktif, lebih informatif, dan tentunya harus user friendly, sehingga dapat meningkatkan daya tarik.

Perkembangan teknologi informasi yang berdampak pada bidang industri membuat banyak perusahaan memanfaatkan peranan Augmented Reality (AR) sebagai media informasi, seperti pada smart building [2], m-commerce [3], media pembelajaran pada berbagai jenis mata pelajaran [4], media pengontrol untuk mendeteksi kandungan nitrogen secara visual di bidang pertanian [5], alat bantu analisis postur kerja Rapid Entire Body Assesment (REBA) dalam ergonomi [6], dan smart grid konsumsi listrik [7]. Oleh sebab itu, pada kasus ini, penerapan AR sebagai media informasi bank baterai di PT. Telkom WITEL Bandung menjadi salah satu pemanfaatan teknologi yang tepat untuk menyampaikan informasi secara digital. AR juga sangat efektif, dikarenakan mampu mengemas media informasi ke dalam bentuk aplikasi yang bersifat friendly, interaktif, dan reliabel, sehingga mudah dipahami.

AR yang diimplementasikan dalam makalah ini berbasis pada objek marker, karena memiliki kelebihan seperti mudah 


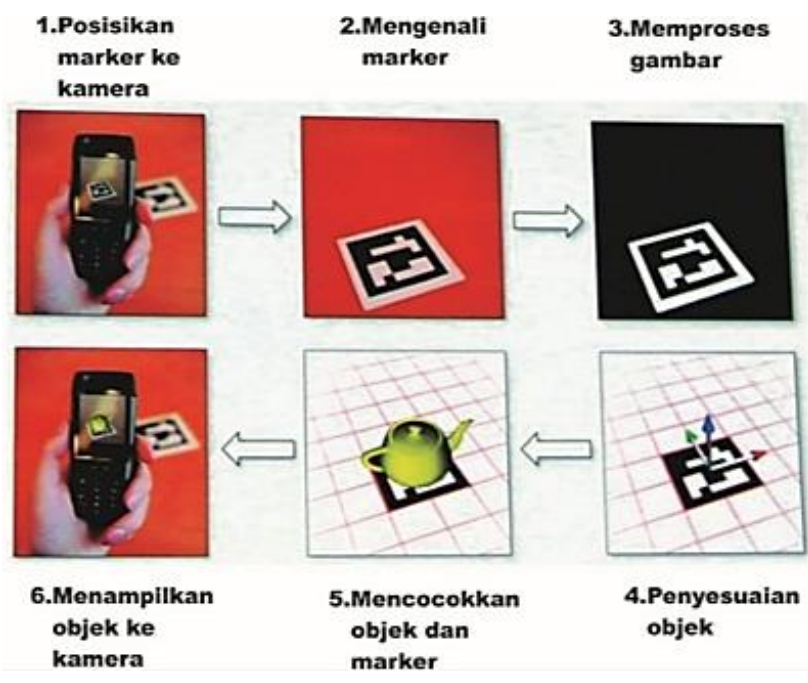

Gbr. 1 AR berbasis marker.

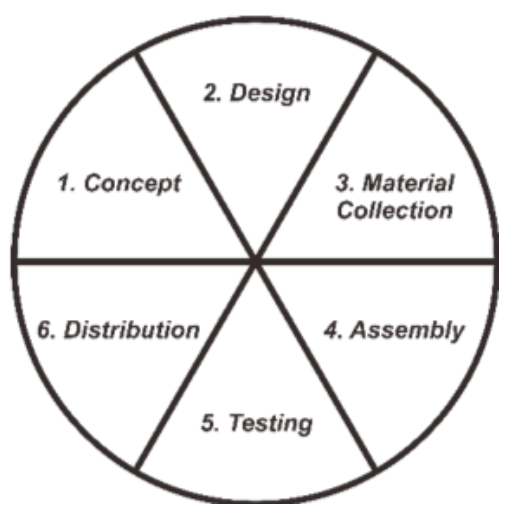

Gbr. 2 Multimedia Development Life Cycle (MDLC).

digunakan, tingkat akurasi yang tinggi, memungkinkan pemrosesan data secara offline, interaksi dengan objek lebih mudah, komputasi yang rendah, hasil yang relatif stabil, dan cocok untuk lingkungan statis atau tetap [8]-[14]. Dalam penerapannya, detail informasi yang tertera pada aplikasi akan disesuaikan dengan kebutuhan pengguna (user) pada pengisian kuesioner, sehingga memiliki nilai guna yang bermanfaat.

\section{AUGMENTED REALITY}

AR merupakan teknologi interaksi yang menggabungkan real world dan virtual world hasil komputasi dari bentuk 2D ataupun 3D. Hasil virtual tersebut kemudian diproyeksikan ke dalam lingkungan nyata [15]-[16]. Untuk penerapannya, teknologi AR harus memiliki scene generator, tracking system, display, dan peranti AR untuk mendukung proses pengolahan citra digital [17].

Scene generator adalah perangkat lunak atau peranti yang memiliki tugas melakukan rendering pada setiap scene. Tracking system yang menjadikan kamera peranti AR sebagai komponen utama harus mampu memproyeksikan objek dalam keadaan statis maupun dinamis dengan menyelaraskan objekobjek di dunia nyata dan virtual secara benar dan akurat. Sedangkan dari segi tampilan, faktor penting yang harus diperhatikan dalam membangun sistem AR adalah resolusi, titik pandang, fleksibilitas, dan tracking area [18].

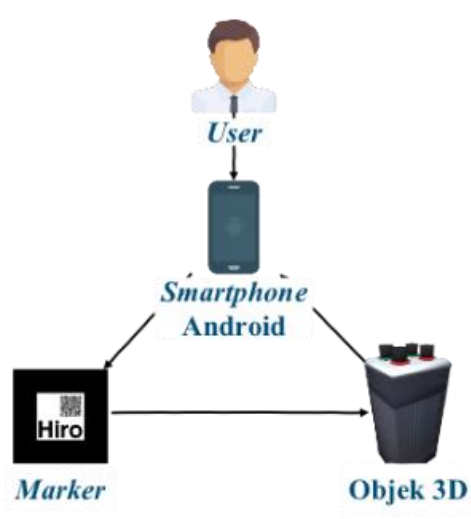

Gbr. 3 Diagram ilustrasi sistem media informasi.

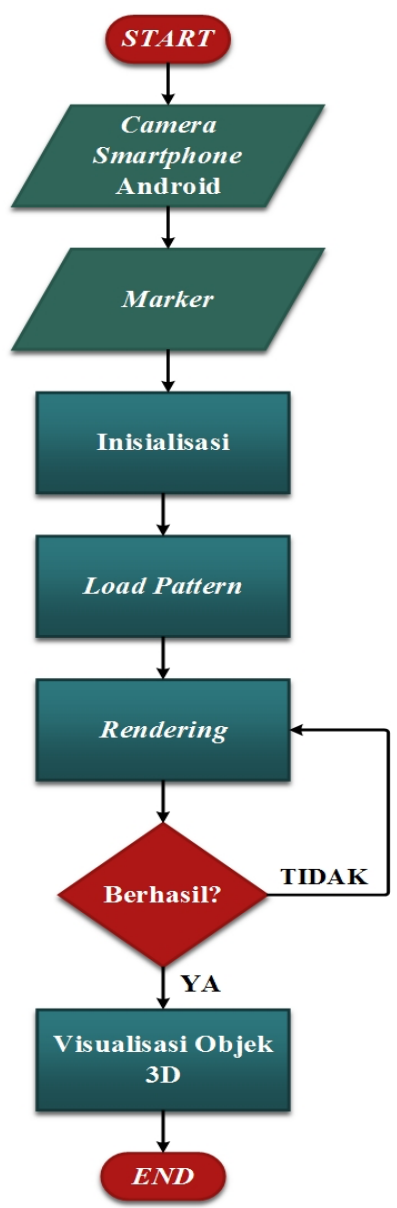

Gbr. 4 Flowchart sistem media informasi bank baterai.

AR bekerja dengan melakukan pengolahan data dan informasi terhadap objek yang terdeteksi bentuk, pola, serta ukurannya dan kemudian menampilkannya kepada pengguna. AR berbasis marker, atau disebut juga dengan marker based tracking, adalah metode yang menggunakan penanda (marker) atau image target sebagai objek pengenal dari suatu objek yang akan divirtualisasikan ke lingkungan nyata oleh sistem. Marker yang digunakan pada umumnya berwarna hitam dan putih yang bentuk, pola, serta ukurannya sudah dikenali oleh sistem. Tidak menutup kemungkinan marker atau image target yang digunakan merupakan gambar dengan banyak warna. 


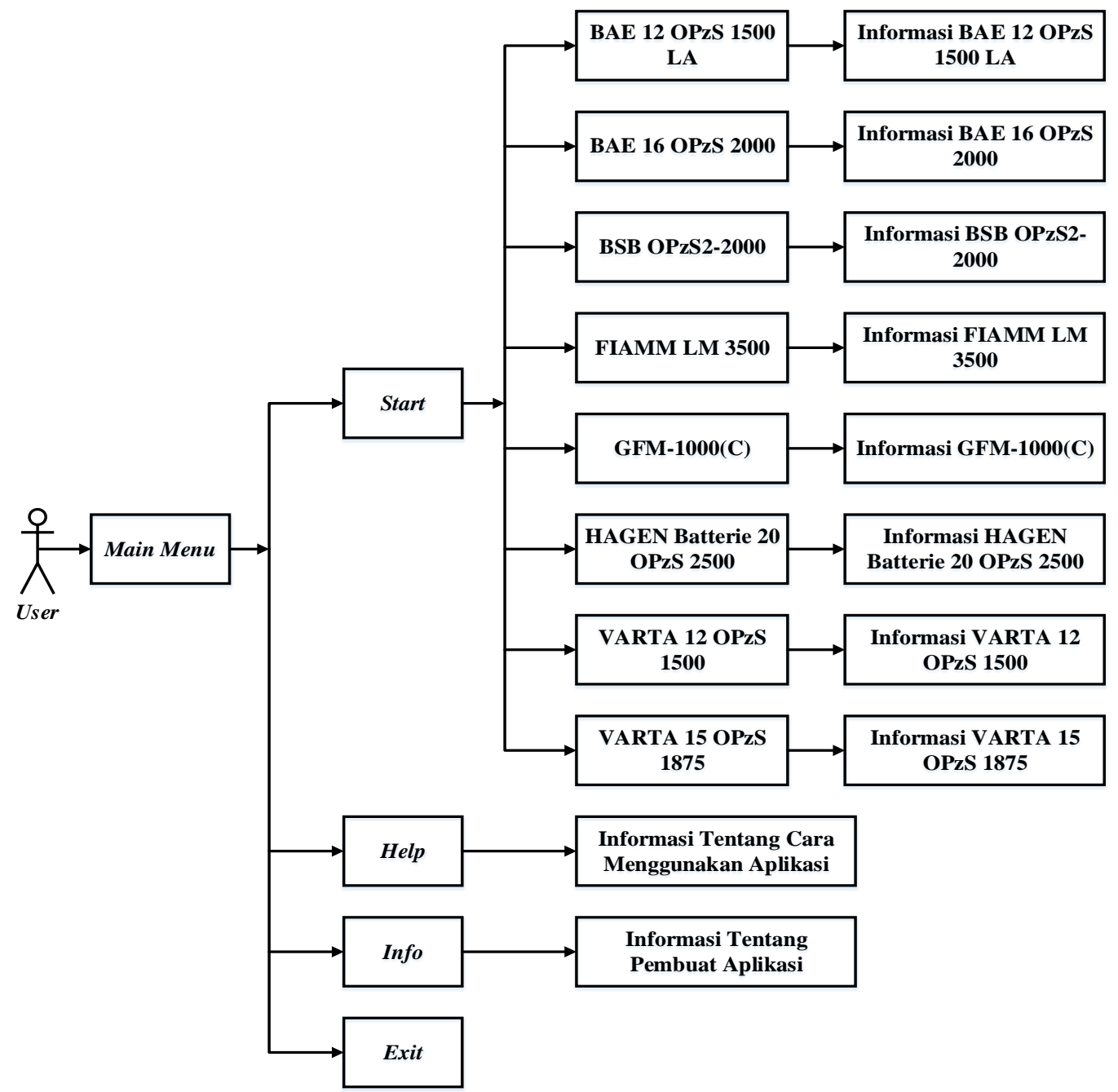

Gbr. 5 Use case diagram aplikasi sistem media informasi bank baterai.

Dalam penerapannya, AR berbasis marker memerlukan kamera untuk mendeteksi marker, sehingga sistem dapat melakukan pengolahan data dan informasi seperti alur yang ditunjukkan pada Gbr. 1 [19]. Marker merupakan hal penting dalam teknologi AR, karena berfungsi sebagai trigger yang akan dikenali oleh kamera untuk menjalankan aplikasi AR [20].

\section{A. Metode Luther-Sutopo}

Metodologi pengembangan multimedia atau Multimedia Development Life Cycle (MDLC) terbagi dalam enam tahap [21], yaitu konsep, desain, pengumpulan material, perakitan, pengujian, dan pendistribusian yang harus dilakukan secara berurutan [22]. Secara umum, siklus MDLC ditunjukkan pada Gbr. 2 [23]. Pada penelitian ini, perancangan aplikasi AR menggunakan metodologi berbasis MDLC.

\section{B. Bank Baterai}

Bank baterai adalah sekumpulan baterai yang disusun menjadi satu untuk membentuk sistem backup daya ketika sumber dari catuan utama terputus. Implementasi bank baterai yang ada di PT. Telkom WITEL Bandung digunakan untuk menjaga agar perangkat-perangkat yang ada dapat beroperasi ketika sumber daya dari PLN mengalami mati total atau terputus. Pentingnya menjaga kondisi perangkat untuk terus beroperasi menjadi upaya antisipasi sebelum terjadinya kerugian yang besar bagi perusahaan. Bank baterai yang ada di PT. Telkom WITEL Bandung terdiri atas delapan tipe, yaitu sebagai berikut.

- BAE 12 OPzS 1500 LA

- BAE 16 OPzS 2000

- BSB OPzS2-2000

- FIAMM LM 3500

- GFM-1000(C)

- HAGEN Batterie $20 \mathrm{OPzS} 2500$

- VARTA 12 OPzS 1500

- VARTA 15 OPzS 1875

GFM-1000(C) menjadi satu-satunya baterai kering yang ada di PT. Telkom WITEL Bandung, sedangkan selebihnya merupakan baterai basah. Terdapat tiga mode yang diatur secara otomatis oleh sistem bank baterai yang ada di PT. Telkom WITEL Bandung, yaitu boost charging, float charging, dan discharge. 


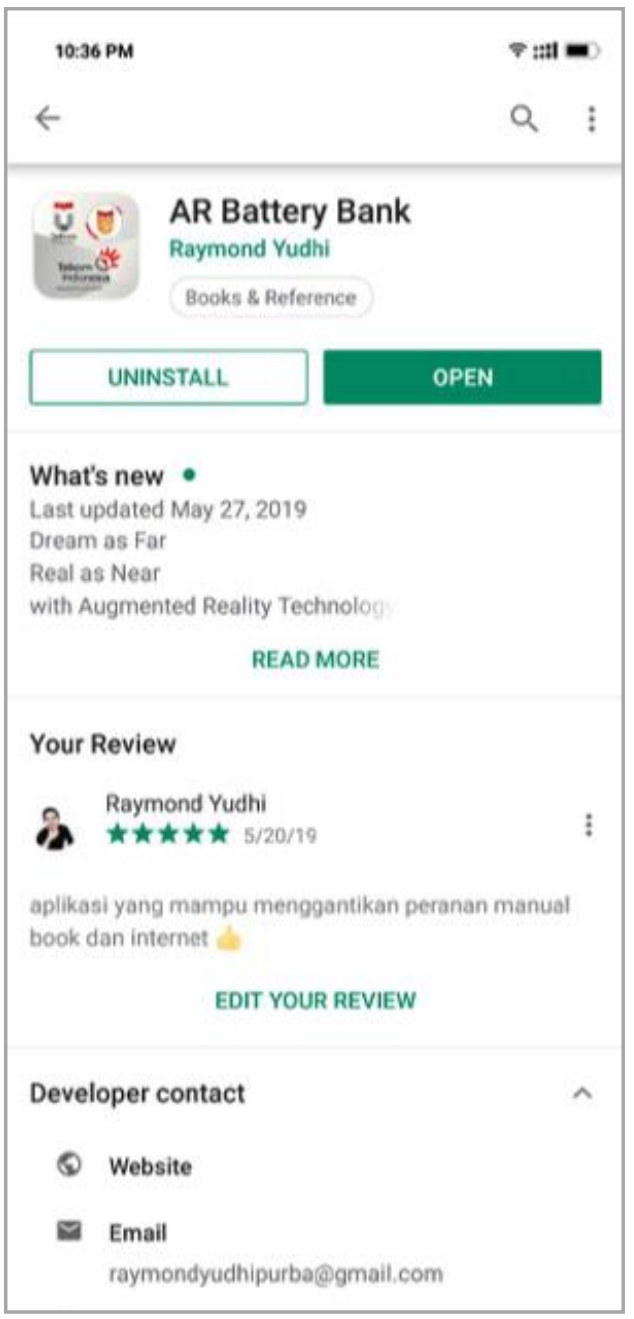

Gbr. 6 Aplikasi AR Battery Bank.
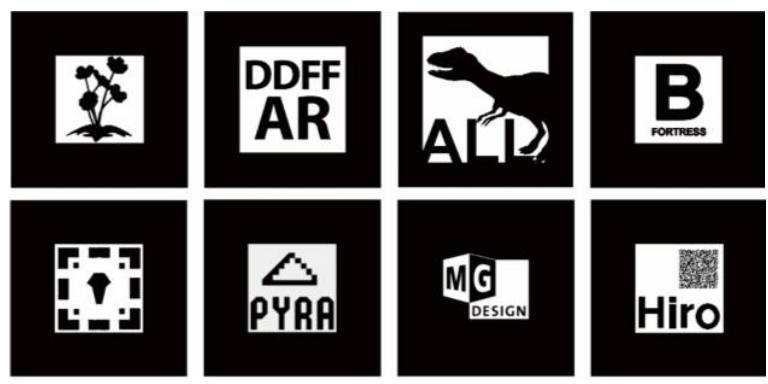

Gbr. 7 Kartu marker aplikasi AR Batterv Bank.

1) Boost Charging: Boost charging adalah mode dengan kondisi bank baterai baru saja digunakan untuk melakukan backup daya, sehingga kapasitas pada baterai sudah banyak terpakai dan perlu dilakukan pengisian daya secara cepat. Baterai-baterai yang ada perlu diisi ulang secara cepat untuk mengantisipasi jika terjadi lagi pemadaman listrik dari PLN, sehingga kapasitas yang terisi selama boost charging sudah siap untuk digunakan kembali.

2) Float Charging: Float charging adalah mode dengan kapasitas bank baterai sudah terisi penuh dan pengisian daya tetap perlu dilakukan. Hal ini dilakukan untuk menjaga level
TABEL I

Hasil PenguJian FungSiOnALitas

\begin{tabular}{|c|c|c|c|c|c|c|c|}
\hline \multirow{2}{*}{$\begin{array}{c}\text { Skenario } \\
\text { Pengujian }\end{array}$} & \multirow{2}{*}{$\begin{array}{c}\text { Target } \\
\text { Objek 3D }\end{array}$} & \multicolumn{5}{|c|}{ Uji Coba } & \multirow{2}{*}{$\begin{array}{c}\text { Hasil } \\
(\%)\end{array}$} \\
\hline & & 1 & 2 & 3 & 4 & 5 & \\
\hline $\begin{array}{l}\text { Main } \\
\text { Menu }\end{array}$ & $\begin{array}{l}\text { Start, Help, } \\
\text { Info, Exit }\end{array}$ & $\checkmark$ & $\checkmark$ & $\checkmark$ & $\checkmark$ & $\checkmark$ & $100 \%$ \\
\hline $\begin{array}{l}\text { Memilih } \\
\text { Submenu } \\
\text { Home }\end{array}$ & $\begin{array}{l}\text { Berlaku untuk } \\
\text { semua kondisi }\end{array}$ & $\checkmark$ & $\checkmark$ & $\checkmark$ & $\checkmark$ & $\checkmark$ & $100 \%$ \\
\hline \multirow{8}{*}{$\begin{array}{l}\text { Memilih } \\
\text { Submenu } \\
\text { Identify }\end{array}$} & $\begin{array}{c}\text { BAE } 12 \\
\text { OPzS } 1500 \\
\text { LA }\end{array}$ & $\checkmark$ & $\checkmark$ & $\checkmark$ & $\checkmark$ & $\checkmark$ & $100 \%$ \\
\hline & $\begin{array}{c}\text { BAE 12 } \\
\text { OPzS 2000 }\end{array}$ & $\checkmark$ & $\checkmark$ & $\checkmark$ & $\checkmark$ & $\checkmark$ & $100 \%$ \\
\hline & $\begin{array}{c}\text { BSB OPzS2- } \\
2000\end{array}$ & $\checkmark$ & $\checkmark$ & $\checkmark$ & $\checkmark$ & $\checkmark$ & $100 \%$ \\
\hline & $\begin{array}{l}\text { FIAMM LM } \\
3500\end{array}$ & $\checkmark$ & $\checkmark$ & $\checkmark$ & $\checkmark$ & $\checkmark$ & $100 \%$ \\
\hline & $\begin{array}{c}\text { GFM- } \\
1000(C)\end{array}$ & $\checkmark$ & $\checkmark$ & $\checkmark$ & $\checkmark$ & $\checkmark$ & $100 \%$ \\
\hline & $\begin{array}{c}\text { HAGEN } \\
\text { Batterie } 20 \\
\text { OPzS } 2500 \\
\end{array}$ & $\checkmark$ & $\checkmark$ & $\checkmark$ & $\checkmark$ & $\checkmark$ & $100 \%$ \\
\hline & $\begin{array}{l}\text { VARTA } 12 \\
\text { OPzS } 1500\end{array}$ & $\checkmark$ & $\checkmark$ & $\checkmark$ & $\checkmark$ & $\checkmark$ & $100 \%$ \\
\hline & $\begin{array}{l}\text { VARTA } 15 \\
\text { OPzS } 1875\end{array}$ & $\checkmark$ & $\checkmark$ & $\checkmark$ & $\checkmark$ & $\checkmark$ & $100 \%$ \\
\hline \multirow{8}{*}{$\begin{array}{l}\text { Memilih } \\
\text { Submenu } \\
\text { Details }\end{array}$} & $\begin{array}{c}\text { BAE } 12 \\
\text { OPzS } 1500 \\
\text { LA }\end{array}$ & $\checkmark$ & $\checkmark$ & $\checkmark$ & $\checkmark$ & $\checkmark$ & $100 \%$ \\
\hline & $\begin{array}{c}\text { BAE } 12 \\
\text { OPzS } 2000\end{array}$ & $\checkmark$ & $\checkmark$ & $\checkmark$ & $\checkmark$ & $\checkmark$ & $100 \%$ \\
\hline & $\begin{array}{c}\text { BSB OPzS2- } \\
2000\end{array}$ & $\checkmark$ & $\checkmark$ & $\checkmark$ & $\checkmark$ & $\checkmark$ & $100 \%$ \\
\hline & $\begin{array}{l}\text { FIAMM LM } \\
3500\end{array}$ & $\checkmark$ & $\checkmark$ & $\checkmark$ & $\checkmark$ & $\checkmark$ & $100 \%$ \\
\hline & $\begin{array}{c}\text { GFM- } \\
1000(C)\end{array}$ & $\checkmark$ & $\checkmark$ & $\checkmark$ & $\checkmark$ & $\checkmark$ & $100 \%$ \\
\hline & $\begin{array}{c}\text { HAGEN } \\
\text { Batterie } 20 \\
\text { OPzS } 2500\end{array}$ & $\checkmark$ & $\checkmark$ & $\checkmark$ & $\checkmark$ & $\checkmark$ & $100 \%$ \\
\hline & $\begin{array}{l}\text { VARTA } 12 \\
\text { OPzS } 1500\end{array}$ & $\checkmark$ & $\checkmark$ & $\checkmark$ & $\checkmark$ & $\checkmark$ & $100 \%$ \\
\hline & $\begin{array}{l}\text { VARTA } 15 \\
\text { OPzS } 1875\end{array}$ & $\checkmark$ & $\checkmark$ & $\checkmark$ & $\checkmark$ & $\checkmark$ & $100 \%$ \\
\hline
\end{tabular}

daya baterai tetap stabil dan tidak mengalami penurunan secara signifikan, sehingga baterai-baterai tersebut tidak cepat rusak.

3) Discharge: Discharge adalah mode dengan kondisi bank baterai tidak melakukan pengisian daya karena sedang digunakan untuk melakukan backup daya ketika sumber catuan utama dari PLN terputus.

\section{ARSITEKTUR DAN PERANCANGAN SisteM}

Untuk mendapatkan informasi tentang bank baterai yang ada di PT. Telkom WITEL Bandung, pengguna dapat menggunakan smartphone dengan sistem operasi Android. Kemudian, pengguna mengarahkan kamera dari smartphone tersebut pada posisi marker. Setelah itu, sistem yang dibuat akan mengenali bentuk, pola, serta ukuran dari marker tersebut 


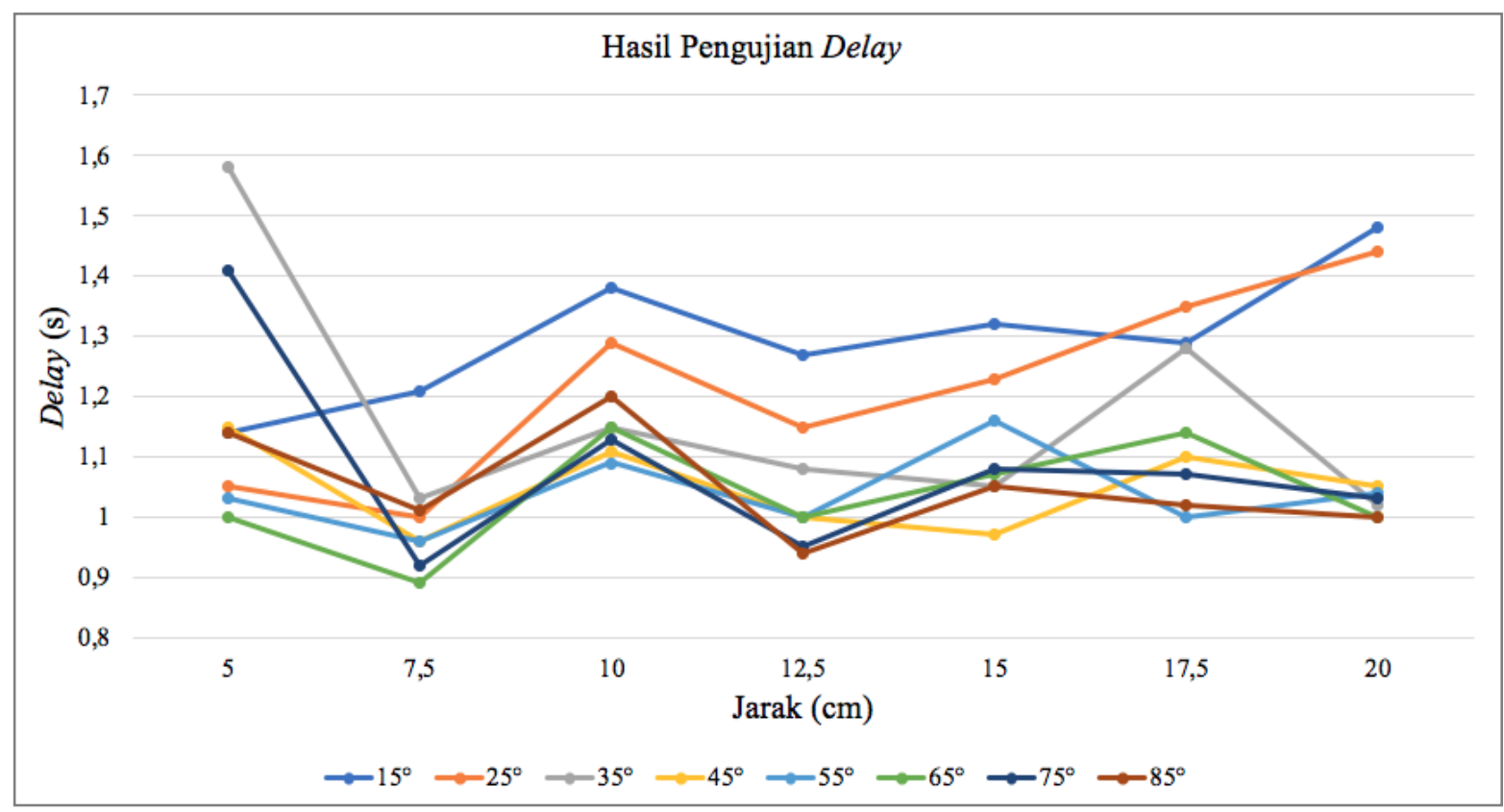

Gbr. 8 Fluktuasi delay berdasarkan jarak.

dan menampilkan objek 3D pada smartphone yang digunakan oleh pengguna, seperti yang diilustrasikan pada Gbr. 3 .

Berdasarkan Gbr. 3, aplikasi menginisialisasi marker yang telah diintegrasikan pada database dan perangkat lunak Vuforia. Selanjutnya, sesuai flowchart pada Gbr. 4, terjadi tahapan load pattern, yaitu setiap titik dan pola yang terdapat pada marker akan diolah. Kemudian terjadi proses rendering objek ke dalam bentuk 3D. Proses rendering ini akan menghasilkan delay sesuai dengan kompleksitas objek yang telah dibuat menggunakan perangkat lunak Blender serta rating marker pada database Vuforia. Jika objek tidak berhasil dirender, maka aplikasi akan melakukan poses rendering ulang. Jika objek berhasil di-render, maka objek akan divisualisasikan dalam bentuk 3D pada screen display smartphone Android.

Struktur aplikasi secara umum dan isi dari menu utama dipaparkan melalui use case diagram pada Gbr. 5. Aplikasi yang telah selesai kemudian dipublikasikan ke Google Play Store, seperti terlihat pada Gbr. 6, dengan kartu marker yang digunakan sesuai dengan Gbr. 7.

\section{PENGUJIAN DAN ANALISIS}

Pada makalah ini dilakukan tiga proses pengujian, yaitu pengujian fungsionalitas, pengujian delay, dan pengujian kuesioner.

\section{A. Pengujian Fungsionalitas}

Pengujian fungsionalitas dilakukan terhadap aplikasi yang telah dibuat pada smartphone Android. Pengujian ini dilakukan untuk memastikan bahwa setiap menu dan submenu pada aplikasi mendapatkan nilai yang valid sesuai dengan fungsinya. Nilai tersebut ditunjukkan melalui persentase keberhasilan setelah dilakukan uji coba sebanyak lima kali terhadap skenario pengujian, seperti yang ditunjukkan pada Tabel I.

Berdasarkan Tabel I, dapat dianalisis bahwa setiap menu dan submenu pada aplikasi mendapatkan nilai yang valid sesuai dengan fungsinya. Hal ini dapat dibuktikan melalui hasil pengujian fungsionalitas yang menunjukkan persentase keberhasilan dari setiap menu dan submenu sebesar $100 \%$.

\section{B. Pengujian Delay}

Pengujian delay dilakukan terhadap kartu marker dengan menggunakan kamera smartphone Android. Pengujian ini dilakukan untuk mengetahui delay rata-rata dari aplikasi selama proses rendering objek 3D bank baterai. Nilai tersebut didapatkan setelah melakukan uji coba delay sebanyak lima kali terhadap jarak dan sudut seperti pada Gbr. 8.

\section{Pengujian Jarak}

Seperti pada beberapa penelitian AR lainnya [1]-[7], pengujian jarak untuk mendeteksi marker wajib dilakukan. Berdasarkan hasil pengujian pada setiap jarak, dapat dianalisis bahwa aplikasi bekerja dengan rata-rata delay keseluruhan sebesar 1,12 detik. Hal ini dapat dibuktikan melalui hasil pengujian delay yang bervariasi, mulai dari 0,89 sampai 1,58 detik.

\section{Pengujian Kuesioner}

Pengisian kuesioner dilakukan oleh lima belas orang karyawan yang bekerja di PT. Telkom WITEL Bandung. Seluruh koresponden ini merupakan karyawan khusus di bagian baterai. Kegiatan ini dilakukan untuk mengetahui tingkat kepuasan pengguna terhadap aplikasi AR yang berperan sebagai media informasi bank baterai. Diawali dengan menggunakan aplikasi, para karyawan kemudian mengisi kuesioner penilaian terhadap tujuh parameter aplikasi, yaitu

1. kemudahan penggunaan (user friendly),

2. tingkat akurasi,

3. kestabilan objek 3D,

4. waktu respons (timing), 


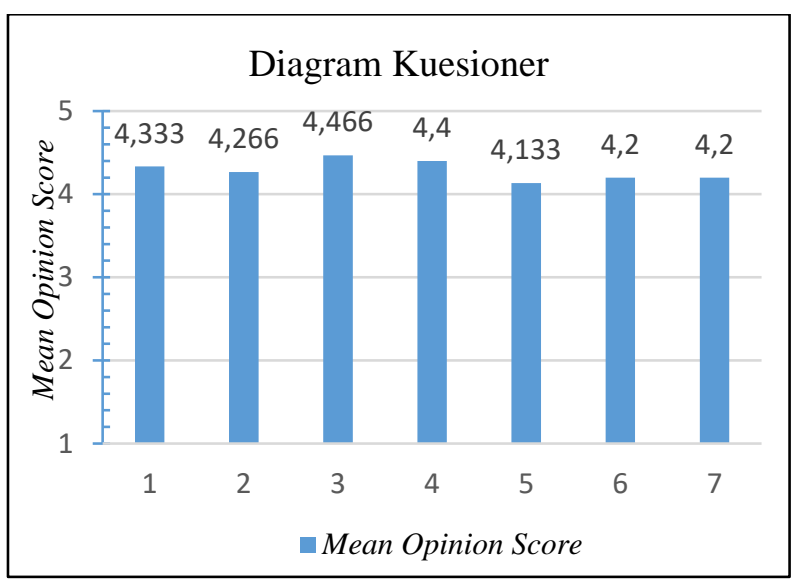

Gbr. 9 Mean opinion score aplikasi media informasi.

TABEL II

HASIL POST-KUESIONER

\begin{tabular}{|c|c|c|c|c|c|}
\hline \multirow{2}{*}{ Parameter } & \multicolumn{5}{|c|}{ Tingkat Kepuasan } \\
\cline { 2 - 6 } & $\mathbf{1}$ & $\mathbf{2}$ & $\mathbf{3}$ & $\mathbf{4}$ & $\mathbf{5}$ \\
\hline 1 & 0 & 0 & 0 & 5 & 10 \\
\hline 2 & 0 & 0 & 0 & 6 & 9 \\
\hline 3 & 0 & 0 & 0 & 3 & 12 \\
\hline 4 & 0 & 0 & 0 & 4 & 11 \\
\hline 5 & 0 & 0 & 0 & 8 & 7 \\
\hline 6 & 0 & 0 & 0 & 7 & 8 \\
\hline 7 & 0 & 0 & 0 & 7 & 8 \\
\hline
\end{tabular}

5. komunikasi interaktif,

6. tingkat keandalan (reliable), dan

7. hasil desain objek 3D.

Berdasarkan tujuh parameter tersebut, diberikan lima kategori penilaian tingkat kepuasan pengguna terhadap aplikasi yang telah digunakan, dari skala 1 sampai dengan 5 berturutturut adalah sangat tidak baik, tidak baik, cukup, baik, dan sangat baik. Adapun hasil pengisian post-kuesioner yang menunjukkan jumlah responden berdasarkan tingkat kepuasan pada masing-masing parameter tertera di Tabel II.

Berdasarkan hasil yang ditunjukkan pada Tabel II, dilakukan perhitungan nilai rata-rata menggunakan metode Mean Opinion Score (MOS) [24]. Setelah dilakukan perhitungan secara matematis, dihasilkan MOS dari ketujuh parameter yang ada. Adapun hasil dari masing-masing parameter disajikan dengan menggunakan diagram batang pada Gbr. 9 .

Berdasarkan Gbr. 9, dapat dianalisis bahwa aplikasi memiliki bobot nilai yang baik. Hal ini dapat dibuktikan melalui hasil MOS pada pengujian kuesioner yang bervariasi, mulai dari 4,1 sampai 4,4, dengan semua parameter bernilai lebih dari 4, melebihi bobot baik pada tingkat kepuasan.

\section{KESIMPULAN}

Berdasarkan hasil pengujian yang telah dilakukan, dapat diambil beberapa kesimpulan bahwa aplikasi media informasi bank baterai di PT. Telkom Witel Bandung bersifat friendly (MOS 4,3), interaktif (MOS 4,1), dan reliabel (MOS 4,2). Hasil pengujian delay menunjukkan bahwa aplikasi memiliki waktu delay yang kecil, yaitu kurang dari 2 detik. Waktu delay terkecil dari proses rendering diperoleh pada sudut $65^{\circ}$ dengan jarak $7,5 \mathrm{~cm}$, yaitu 0,89 detik, sedangkan waktu delay terbesar dari proses rendering diperoleh pada sudut $35^{\circ}$ dengan jarak $5 \mathrm{~cm}$, yaitu 1,58 detik. Diketahui juga bahwa rata-rata delay keseluruhan sebesar 1,12 detik. Hasil pengujian fungsionalitas menunjukkan bahwa aplikasi sudah berjalan dengan baik dan siap untuk digunakan sebagai sistem media informasi bank baterai di PT. Telkom WITEL Bandung yang dapat diunggah pada Google Play Store.

\section{UCAPAN TERIMA KASIH}

Terima kasih disampaikan kepada Universitas Telkom yang telah memberikan fasilitas sehingga penelitian ini selesai dilakukan.

\section{REFERENSI}

[1] Kementerian Kesehatan RI, "InfoDatin Pusat Data dan Informasi Kementerian Kesehatan RI: Situasi Kesehatan Kerja,” 2015.

[2] Z. Zainuddin, I.S. Areni, dan R. Wirawan, "Aplikasi Augmented Reality pada Sistem Informasi Smart Building," Jurnal Nasional Teknik Elektro dan Teknologi Informasi (JNTETI), Vol. 5, No. 3, hal. 207-216, Sep. 2016.

[3] A.M. Bachtiar dan A. Bardansyah, "Pembangunan Class Library untuk Domain Product Management di Aplikasi M-Commerce pada Android,' Jurnal Nasional Teknik Elektro dan Teknologi Informasi (JNTETI), Vol. 6, No. 3, hal. 235-242, Sep. 2017.

[4] R. Budiawan, T.N. Damayanti, dan D.A. Nurmantris, "Pembelajaran Elektromagnetika Terapan Berbasis Augmented Reality: Kasus Sistem Koordinat," Jurnal Nasional Teknik Elektro dan Teknologi Informasi (JNTETI), Vol. 6, No. 4, hal. 436-444, Nov. 2017.

[5] E.B. Setiawan dan R. Herdianto, "Penggunaan Smartphone Android sebagai Alat Analisis Kebutuhan Kandungan Nitrogen pada Tanaman Padi," Jurnal Nasional Teknik Elektro dan Teknologi Informasi (JNTETI), Vol. 7, No. 3, hal. 273-280, Sep. 2018.

[6] D.K. Baroroh dan R. Ramadhan, "Perancangan Alat Bantu Analisis Rapid Entire Body Assessment (REBA) Berbasis Aplikasi Android," Jurnal Nasional Teknik Elektro dan Teknologi Informasi (JNTETI), Vol. 7, No. 3, hal. 266-272, Sep. 2018.

[7] E. Susilo, F.D. Wijaya, dan R. Hartanto, "Perancangan dan Evaluasi User Interface Aplikasi Smart Grid Berbasis Mobile Application," Jurnal Nasional Teknik Elektro dan Teknologi Informasi (JNTETI), Vol. 7, No. 2, hal. 150-157, Jun. 2018.

[8] J.C.P. Cheng, K. Chen, dan W. Chen, "Comparison of Marker-based AR and Markerless AR: A Case Study on Indoor Decoration System," Lean and Computing in Construction Congress (LC3) 2017: Volume I Proceedings of the Joint Conference on Computing in Construction (JC3), 2017, hal. 483-490.

[9] W. Li, A. Nee, dan S. Ong, "A State-of-the-Art Review of Augmented Reality in Engineering Analysis and Simulation," Multimodal Technologies and Interaction, Vol. 1, No. 3, hal. 17, Sep. 2017.

[10] H. Kolivand, A. El-Rhalibi, M. Tajdini, S. Abdulazeez, dan P. Praiwattana, "Cultural Heritage in Marker-Less Augmented Reality: A Survey," dalam Advanced Methods and New Materials for Cultural Heritage Preservation, D. Turcanu-Carutiu dan R.-M. Ion, Ed., London, UK: Intechopen, 2019, hal. 1-22.

[11] A. Ufkes dan M. Fiala, "A Markerless Augmented Reality System for Mobile Devices," 2013 International Conference on Computer and Robot Vision, 2013, hal. 226-233.

[12] S. Ćuković, M. Gattullo, F. Pankratz, G. Devedžić, E. Carrabba, dan K Baizid, "Marker Based vs. Natural Feature Tracking Augmented Reality Visualization of the 3D Foot Phantom," The International Conference on Electrical and Bio-medical Engineering, Clean Energy and Green Computing (EBECEGC2015), 2015, hal. 24-31.

[13] B.C. Nugraha dan B. Nurhadiyono, "Komparasi Marker Based Augmented Reality dan Markerless Augmented Reality sebagai Media 
Periklanan Berbasis Website dengan Menggunakan FLARToolkit,' Skripsi, Universitas Dian Nuswantoro, Semarang, Indonesia, Okt. 2014.

[14] M. Mekni dan A. Lemeiux, "Augmented Reality: Applications, Challenges and Future Trends," 13th International Conference on Applied Computer and Applied Computational Science, 2014, hal. 205214.

[15] H. Pratikno, "Kontrol Gerakan Objek 3D Augmented Reality Berbasis Titik Fitur Wajah dengan POSIT," Jurnal Nasional Teknik Elektro dan Teknologi Informasi (JNTETI), Vol. 4, No. 1, hal. 16-24 Jun. 2015.

[16] C. Lai dan C. Wang, "Mobile Edutainment with Interactive Augmented Reality Using Adaptive Marker Tracking," 2012 IEEE 18th International Conference on Parallel and Distributed Systems, 2012 , hal. 124-131.

[17] R. Silva, J.C. Oliveira, dan G.A. Giraldi, "Introduction to Augmented Reality," National Laboratory for Scientific Computation, Petropolis, Brazil, Tech. Report, hal. 1-11, 2003.

[18] R.T. Azuma, “A Survey of Augmented Reality," Presence: Teleoperators and Virtual Environments, Vol. 6, No. 4, hal. 355-385, Agt. 1997.
[19] T. Domhan, "Augmented Reality on Android Smartphones," Dualen Hochschule Baden-Württemberg, Stuttgart, Germany, Study Work, Juni 2010, hal. 1-47.

[20] G. Koutromanos dan L. Avraamidou, "The Use of Mobile Games in Formal and Informal Learning Environments: A Review of the Literature," Educational Media International, Vol. 56, No. 1, hal. 49-65, Jan. 2014

[21] A.C. Luther, Authoring Interactive Multimedia, Boston, USA: AP Professional, 1994.

[22] I. Binanto, Multimedia Digital - Dasar Teori dan Pengembangannya, Yogyakarta, Indonesia: ANDI OFFSET, 2010.

[23] A.H. Sutopo, Multimedia Interaktif dengan Flash, Yogyakarta, Indonesia: Graha Ilmu, 2003.

[24] R.C. Streijl, S. Winkler, dan D.S. Hands, "Mean Opinion Score (MOS) Revisited: Methods and Applications, Limitations and Alternatives," Multimedia Systems, Vol. 22, No. 2, hal. 213-227, Mar. 2016 